\title{
Kepemimpinan Pendidikan Islam Dalam Perspektif Gender
}

\author{
Muhammad Yusuf Noor Khozain ${ }^{1}$,Dimas Afrizal ${ }^{2}$ Astuti Nursangadah $^{3}$
}

Fakultas Agama Islam Universitas Ahmad Dahlan

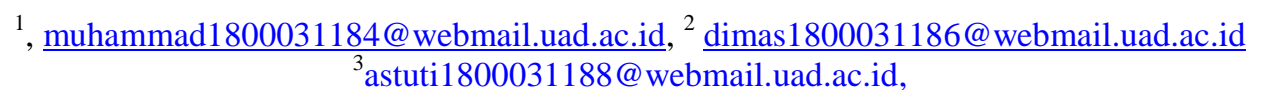

\begin{abstract}
Abstrak
Gaya kepemimpinan pada era sekarang harus dibangun sejak dini dengan berbagai upaya salah satunya dengan pembinaan berkesinambungan. Setiap pemimpin memiliki perbedaan khusus baik itu pemimpin laki-laki ataupun perempuan. Di era sekarang ini atau biasa disebut era globalisasi, istilah gender mungkin sudah tidak asing lagi, karena banyaknya wacana yang sangat berkembang tentang pengaruh gender disemua bidang, terutama dalam hal kepemimpinan di bidang pedidikan islam. Penelitian ini bertujuan mendeskripsikan tentang kepemimpinan pendidikan islam dan gender. Metode yang digunakan yaitu studi pustaka (library research), yang menggunakan sumber-sumber berupa buku-buku dan artikel jurnal yang sesuai. Dalam hasil penelitin ini bahwa kesetaraan gender dalam memimpin khusunya dilembaga pendidikan bukanlah suatu hal yang tabu, karena pemimpin harus mempunyai kemampuan untuk mempengaruhi dan penggerak bagi orang lain bisa berperan baik perempuan atau laki-laki yang mempunyai keterampilan sebagai seorang pemimpin.
\end{abstract}

Kata kunci: kepemimpinan, gender, pendidikan islam

\begin{abstract}
Abstrack
The leadership style in the current era must be built from an early age with various efforts, one of which is continuous coaching. Every leader has special differences, both male and female leaders. In the current era or commonly called the era of globalization, the term gender may be familiar, because there are many highly developed discourses on the influence of gender in all fields, especially in terms of leadership in the field of Islamic education. This study aims to describe the leadership of Islamic education and gender. The method used is library research, which uses appropriate sources in the form of books and journal articles. In the results of this study that gender equality in leading, especially in educational institutions is not a taboo subject, because leaders must have the ability to influence and motivate others to play a role, both women and men who have the skills as a leader.
\end{abstract}

Keywords: leadership, gender, Islamic education 


\section{PENDAHULUAN}

Didalam kehidupan bermasyarakat dominasi kebudayaan ini sangat melekat terkhusus dimasyarakat Indonesia. Sehingga kebudayaan ini memberikan dampat yang cukup besar karena sering terjadinya dominasi kebuyaan. Hal ini akan memberikan dampak ketimpangan dalam masayarakat yang bisa masuk dalam semua aspek termasuk dalam aspek keagamaan. Ketimpangan itu sendiri terjadi karena penyebabnya pemaknaan dan pemahaman ini yang ada sejak dulu yang masih diyakini.(Sukri, 2002)

Menurut pendapat dari Grabruker yang dikutip Darmojuwono(Darmojuwono, 2000) menurutnya cara pandangan pria sebenarnya sudah terbentuk sejak dini, karena secara sadar atau tidak pandangan pria terhadap wanita ini sudah ada sejak awal mulanya sosialisasi. Dilihat dari perkembangan antara laki-laki dan perempuan terdapat pandangan yang membedakan antara kedua gender ini. Dalam sudut pandang ini perkembangan antara laki-laki dan perempuan ini ada perbedaanya dari proses didiknya dan cara dibesarkan dengan cara yang berbeda yang memiliki faktor seperti sosial dan budaya masing-masing yang melatar belakanginya. Jadi mereka memiliki dunia yang berbeda karena proses pertumbuhan dan berkembangnya tidak melalui proses yang sama.

Pembahasan tentang gender biasanya ini membahas tentang laki-laki dan perempuan. Pembahasan gender ini paling banyak pembahasannya tentang perempuan karena perbedaan gender antara laki-laki dan perempuan ini menjadi timpang. Ketimpangan ini dikarenakan tidak tercukupinya hak-hak dasar perempuan, seperti hak untuk memilih jalan sendiri untuk menentukan kehidupannya atau secara otonom (mandiri). Problematika gender berasal dari adanya perlakuan pembedaan. Jika melihat dari sudut pandang Islam pandangan antara laki-laki dan perempuan jika dilihat dari Islam ada perbedaanya, perbedaan ini bukan dilihat semata-mata dari kondisi fisik-biologis antara laki-laki dan perempuan. Perbedaan pandangan antara laki-laki dan perempuan bukan menjadi sebuah alasan untuk meninggikan atau merendahkan martabat dari salah satu jenis gender tersebut.(Sukri, 2002)

Agama Islam ini adalah agama yang memberikan kebaikan atau rahmatan lil'alamin sehingga setiap nilai dari Islam mengandung musawah (kesetaraan), 'adalah (keadilan), dan tasamuh (toleransi). Dari nilai itu menjadikan agama Islam memiliki prinsip tentang kesetaraan anatara laki-laki dan perempuan. Penegakan kebenaran mengenai agama tidak hanya secara subtansi hanya membaca teks-teks yang terdapat dalam Al-Qur'an dan Hadis, akan tetapi juga harus mengimplementasikan ajaran agama dan kondisi sosial yang ada pada lingkuangannya. Jika dilihat banyak permasalahan tentang gender atara lain seperti ketimpangan antara laki-laki dan perempuan, berawal dari sinilah kepemimpinan yang melihat gender menjadi permasalahan, karena kebayakan pemimpin itu dari kalingan kaum adam sehingga ini menjadi budaya bahwa yang harus menjadi pemimpin ialah laki-laki bukan perempuan. Hal ini yang menjadi pokok permasalahan sehingga wanita memiliki sebuah tembok penghalang untuk karna budaya yang sudah ada dan melekat dimasyarakat. (Khairuddin, n.d.)

\section{METODE PENELITIAN}

Penulisan ini menggunakan jenis metode kualitatif melalui pendekatan studi pustaka (library research). Dalam penelitian ini bersifat deskriptif dan menganalisa informasi. Pengumpulan data dilakukan dengan diskusi kelompok dengan menemukan kajian ilmu dan informasi dari berbagai sumber. Penyajian data berupa narasi. Tulisan ini bertujuan menyampaikan dan mengumpulkan data secara rinci tentang kepemimpinan pendidikan islam dalam perspektif gender. Penelitian ini sebagai perbandingangan upaya dalam melakukan tindakan untuk memecahkan persoalan dan menentukan solusi. Penelitian ini menungkap bagaimana kepemimpinan perspektif gender khususnya dalam pendidikan islam. 


\section{HASIL DAN PEMBAHASAN}

\section{Kepemimpinan Pendidikan Islam}

Dalam mewujudkan keadilan gender dalam masyarakat, dibutuhkan peran daripada pendidikan. Pendidikan disamping sebagai instrument untuk mentrasfer norma-norma masyarakat, kemampuan dan pengetahuan manusia juga sebagai instrument dalam mengkaji dan menyampaikan ide-ide nilai baru. Namun pada praktiknya secara khusus, praktek-praktek marginalisasi ini juga merambat pada praktik pendidikan Islam, sebagai contohnya ialah, dalam hal anggapan, perlakun hingga tindakan.

Pendidikan Islam menurut Achmadi (Rohyani, 2015)merupakan segala dan upaya dalam merawat dan menumbuhkembangkan fitrah manusia serta sumberdaya insani yang ada padanya menuju terbentuknya manusia paripurna (Insan Kamil) sesuai dengan norma Islam. Dalam artian manusia yang berimtaq serta memiliki berbagai kompetensi yang teraktualisasikan dalam hubungan dengan Tuhan, antar sesama manusia, dan dengan alam sekitarnya secara baik, positif, dan konstruktif. Di Indonesia, wacana kesetaraan gender bukan sesuatu problem yang baru lagi yang terdengar Indonesia. Dari berbagai sumber referensi seringkali wacana genderdiulas dalam perspektif berbeda. Atau bahkan diskursus menjadi khazanah yang mencakup aspek sosial, budaya, dan agama. Dikalangan akademisi maupun nonakademisi wacana kesetaraan gender akan selalu menjadi distorsi dari zaman ke zaman. Isu-isu ini akan selalu menjadi topik teraktual selama kaum perempuan benar-benar memperoleh haknya dan tidak ada lagi bias gender.

Peran pendidikan sebagaimana dinyatakan Azyumardi azra(Azra, 2019) pendidikan adalah salah satu agen perubahan sosial mengacu pada tiga alasan, Pertama, lembaga pendidikan adalah wadah institusional dimana semua pegawai (laki-laki dan perempuan) mengekspresikan segala potensinya, mengaktualisasikan dan mendefinisikan identitas dirinya. Kedua, Lembaga pendidikan merupakan institusi dinamis yang menyiapkan, memproduksi, dan mengembangkan potensi sumber daya. Ketiga, lembaga pendidikan memproduksi idiologi, atau doktrin tertentu, baik melalui proses pendidikan, nilainilai diperkenalkan, ditransmisi, dan ditransformasikan. Akibatnya proses pendidikan pengajaran dan lembaga pendidikan memainkan peranan penting dalam menggariskan dan merealisasikan arah pembangunan yang melahirkan keadilan gender. Dengan pendidikan Islam yang membawa misi kesetaraan harapannya dapat mewujudkan pendidikan yang berkeadilan gender.

Berbasis pada kegelisahannya terhadap kenyataan sosial perempuan dalam Islam yang banyak mengalami subordinasi dan pelecehan ditengah kuatnya budaya patriarkhi di dalam masyarakat Islam. Islam sangat mengapresiasi dengan keberadaan perempuan yang dianggap mempunyai kedudukan yang setara baik dalam bidang agama maupun sosial berbasis pada nilai manusia universal yang banyak di temukan dalam teks-teks agama.

Dalam hal syari'at Islam dalam memposisikan perempuan tampak belum mendapatkan tempat yang layak. Hal itu dikarenakan masih banyaknya penyimpangan dan ketimpangan yang terjadi dalam memahami kedudukan perempuan, perempuan dianggap kaum yang tak berdaya selamanya terikat dengan laki-laki yang jika perempuan telah menikah maka hak kekuasaan diambil alih oleh suaminya. Ironisnya, dalam memahami hal tersebut dirasa ada pondasi kuat yang berasal dari sumber teks keagamaan, misalnya banyak yang merujuk pada kitab-kitab fiqih melalui hadist Nabi yang dengan jelas dan terang menyebutkan bahwa suami diperbolehkan memukul istrinya apabila ia tidak mau untuk digauli, kemudian ketika pergi keluar rumah ia tidak meminta izin kepada suaminya, maka suami berhak memukulinya. Dan sekarang, dengan pengamatan sepintas saja perempuan selalu menjadi manusia kedua, jika kita berpikir perempuan Islam, maka yang terbayang adalah segala jenis inferioritas. Wanita tidak boleh memimpin, membantah ajakan suami, pergi sendirian, bersuara keras, dan harus mendidik anak, taat kepada suami atau tinggal dirumah. Semua ini adalah larangan sekaligus keharusan yang harus dijalankan perempuan Islam. 
Dalam pemikiran seorang pakar teologi Muslim India yang bernama Asghar Ali Einggeiner, ia juga merupakan seorang yang ahli dalam mengkaji tentang perempuan, lebih lanjut ia mengatakan bahwa secara historis, laki-laki telah mendominasi di segala aspek dalam masyarakat sepanjang zaman, hanya saja laki-laki tidak mendominasi pada masyarakat matriarkal yang dari segi jumlahnya tidak terlalu banyak. Maka muncullah dari sini ajaran tentang ketidaksetaraan antara laki-laki dan perempuan, tugas dan tanggung jawab seorang perempuan pun sangat dibatasi, mulai tugasnya di rumah, di dapur, dan bahkan dia dikekang dalam mengambil keputusan di luar wilayahnya.(Bush \& Coleman, 2006)

\section{Gender}

Istilah gender diprakarsai pertama kali oleh seorang tokoh yang bernama Robert Stoller (Riant, 2008), beliau mengatakan bahwa gender itu berdasarkan dari sifat sosial budaya dengan membandingkan ciri fisik biologis seseorang untuk membedakan karakter manusia. Ann Oakley adalah orang yang berjasa dalam mengembangkan istilah gender. Ia mengatakan bahwa gender itu diciptakan untuk simbol yang digunakan manusia dibangun oleh kebudayaan manusia dan sebagai proses sosial dalam jangka panjang antara perempuan dan lai-laki, yang hanya sebuah perbedaan jenis kelamin yang bukan karena genetika dan bukan kodrat Tuhan.

Menurut Julia Claves Mosse(Mosse, 2007), bahwa geder itu adalah instrumen peran yang yang dikatakan kepada orang lain bahwa kita itu feminim atau maskulin. Dalam paradigma gendernya, Mufidah mengatakan(Mufidah, 2003) bahwa gender dibentuk dan ditentukan oleh beberapa faktor yang membentuk kemudian disalurkan, diperkuat, bahkan dikontruksi melalui sosial atau kultural dilanggengkan dengan penafsiran agama dan mitos seolah-olah bahwa menjadi kodrat laki-laki dan perempuan.

Gender dikategorikan sebagai persoalan dalam pembagian peran antara laki-laki dan perempuan dalam masyarakat yang dikonstruksikan oleh masyarakat itu sendiri. Sedangakan gender dalam bahasa inggris berarti jenis kelamin yang arti ini menjadi rancu karena menyamakan gender dan seks. Dalam Webster's New World Dictionary, gender diartikan sebagai perbedaan yang tampak antara laki-laki dan perempuan dilihat dari segi nilai dan tingkah laku(Romdloni, 1978). Gender sering di samakan dengan jenis kelamin (seks) padahal keduanya berbeda. Sex (jenis kelamin) yaitu pensifatan atau jenis kelamin secara biologis dan melekat pda kelamin secara permanen perempuan dan laki-laki yang tidak bisa ditukar. Yang artinya jika laki-laki bertukar jenis kelamin dengan perempuan, maka tetap tidak bisa melakukan reproduksi seperti perempuan, karena tidak ada rahim dan sel telur. Meski memiliki kelamin vagina. Begitu juga perempuan yang yang mengganti kelaminnya sebagai laki-laki dan memiliki penis namun tetap tidak bisa membuahi karena tidak mempunyai spermatozoa.(Umi, 2008).

Baik konsep ataupun definisi tentang gender tidak disebutkan langsung oleh Al Quran, tetapi jika berbicara mengenai gender, Al Quran menggunakan beberapa kata yang digunakan untuk menelaah dalam permasalahan kesetaraan laki-laki dan perempuan, kata yang dipandang ada kemiripan atau mendekati kata gender jika dilihat dari peran fungsi dan relasi adalah kata ar-rijal dan an-nisa. Kata alrajul menuntut beberapa kriteria yang tidak hanya mengacu pada jenis kelamin, tetapi juga kualifikasi budaya tertentu, khususnya sifat kejantanan. Kata an-nisa ialah gender perempuan, setara dengan al-rijal yang berarti gender laki-laki. Penggunaan kata an-nisa di dalam Al-Quran terbatas dibandingkan penggunaan al-rijal. Kata al-rijal bisa gender laki-laki, orang, menunjuk benda, menunjuk pengertian nabi, budak dan tokoh masyarakat. Sedangkan kata an-nisa menunjukkan dalam arti gender dan isteriisteri. Keutamaan ajaran islam adalah salah satunya tidak membeda bedakan manusia berdasarkan kasta, jenis kelamin dan ras.(Wahyuni et al., 2020) Konsep dasar islam yang harus dipahami bersama adalah Allah menciptakan manusia, perempuan, laki-laki untuk menjadi pemimpin seperti yang telah disebutkan di dalam Al Quran QS. Al-Baqarah:30 yaitu: 


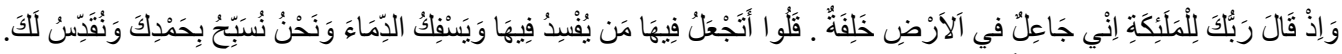

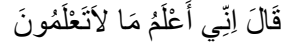

Artinya : "dan Ingatlah ketika Tuhanmu berfirman kepada para Malaikat: "Sesungguhnya Aku hendak menjadikan seorang khalifah di muka bumi". Mereka berkata: "Mengapa Engkau hendak menjadikan (khalifah) di bumi itu orang yang akan membuat kerusakan padanya dan menumpahkan darah, padahal kami senantiasa bertasbih dengan memuji Engkau dan mensucikan Engkau?" Tuhan berfirman: "Sesungguhnya Aku mengetahui apa yang tidak kamu ketahui".

\section{Kepemimpinan Pendidikan Islam Perspektif Gender}

Kepemimpinan gender dalam Islam mempunyai posisi yang sangat penting untuk diperhatikan dan dijalankan dengan sebaik mungkin. Pandangan Islam mengenai kepemimpinan harus dipegang oleh orang yang mampu dan dapat menempatkan diri sebagai pembawa kebenaran dengan memberi contoh teladan yang baik, karena pemimpin adalah uswatun hasanah (teladan yang baik). Ada pendapat yang memperbolehkan perempuan memimpin Negara, ada pula pendapat yang tidak memperbolehkannya. Masing-masing pendapat tersebut diperkuat dengan dalil yang bersumber pada al-Qur'an dan hadits.

Hadits yang menjadi rujukan tentang larangan menjadi kepala Negara bagi perempuan adalah sebuah Hadits yang diriwayatkan oleh Abu Bakrah yang artinya "Tidak akan bahagia suatu kaum yang menyerahkan urusan mereka kepada perempuan". Adapun secara umum, Islam tidak melarang perempuan menjadi kepala pemerintahan. Hal itu disebabkan laki-laki dan perempuan adalah sesama hamba Allah yang memiliki kedudukan yang sama di sisi Allah dan akan mendapat balasan yang sama atas amal perbuatannya, seperti dalam QS. Adz-Dzariyaat ayat 56, QS. Al-Hujurat ayat 13, dan QS. AnNahl ayat 97.

Kepemimpinan pendidikan merupakan kepemimpinan yang diterapkan dalam bidang (organisasi) pendidikan. Apabila dianalisis, kepemimpinan pendidikan terdiri dari dua istilah yaitu kepemimpinan dan pendidikan. pendidikan itu sendiri secara preskriptif dapat dimaknai sebagai upaya manusia untuk membantu manusia lainnya menjadi dewasa dan matang secara intelektual, moral dan sosial, sementara itu dalam UU Sisdiknas No. 20 tahun 2003 disebutkan bahwa Pendidikan adalah usaha sadar dan terencana untuk mewujudkan suasana belajar dan proses pembelajaran agar peserta didik secara aktif mengembangkan potensi dirinya untuk memiliki kekuatan spiritual keagamaan, pengendalian diri, kepribadian, kecerdasan, akhlak mulia, serta keterampilan yang diperlukan dirinya, masyarakat, bangsa dan Negara. Mengacu pada pengertian tersebut, maka kepemimpinan pendidikan dapat dimaknai sebagai kemampuan mempengaruhi (suatu hubungan pengaruh) orang atau pihak lain baik langsung ataupun tidak langsung guna terlaksananya upaya membantu proses pendewasaan manusia sesuai dengan tujuan yang telah ditentukan.

Kepemimpinan dalam Islam mempunyai posisi yang sangat penting untuk diperhatikan dan dijalankan dengan sebaik mungkin. Melihat pentingnya kepemimpinan ini, Islam mengharuskan dalam setiap perkumpulan, baik pada skala kecil maupun besar harus ada pemimpinnya. Pandangan Islam mengenai kepemimpinan harus dipegang oleh orang yang mampu dan dapat menempatkan diri sebagai pembawa kebenaran dengan memberi contoh teladan yang baik, karena pemimpin adalah uswatun hasanah (teladan yang baik).

Dalam asas dan prinsip ajaran Islam, pemimpin adalah hamba Allah, membebaskan manusia dari ketergantungan kepada siapa pun, melahirkan konsep kebersamaan antarmanusia, menyentuh aspek hubungan manusia dengan manusia, dan alam sekitar, membenarkan orang taat kepada pemimpin selama tidak berbuat maksiat dan melanggar aturan Allah, mengajarkan bahwa kehidupan dunia adalah bagian dari perjalanan akhirat, memandang kekuasaan dan kepemimpinan adalah bagian integral dari ibadah, kepemimpinan merupakan tanggung beban dan tanggung jawab, bukan kemuliaan. Kepemimpinan membutuhkan keteladanan dan wujud, bukan kata dan retorika, serta senantiasa bertutur santun.

Islam menempatkan perempuan dalam posisi yang tinggi. Beberapa pranata sosial Arab jahiliyah yang diskriminatif, bahkan cenderung tidak menghargai perempuan, berhasil diperbaiki. Di antaranya adalah masalah warisan. Semula, perempuan tidak berhak mendapat warisan, bahkan perempuan di zaman jahiliyah dipandang sebagai barang yang dapat diwariskan. Tradisi itu hilang setelah Islam 
diturunkan dan perempuan mendapat kedudukan dan hak yang setara dengan laki-laki. Dalam bidang politik, banyak perempuan muslimah yang ikut dalam kegiatan politik praktis. Pada masa selanjutnya, ketika pemerintahan Islam dipegang oleh daulah yang berdasarkan dinasti, terdapat beberapa perempuan yang diangkat sebagai kepala Negara, seperti Sajarat Al-Dur (Mesir), Padishah Khatun (dinasti Mongol), dan Sultanat Taj Al-Alam Safiataddin Shah (Aceh).(Yatazaka, 2014)

Selain pendapat yang memperbolehkan perempuan memimpin Negara, ada pula pendapat yang tidak memperbolehkannya. Hal ini mengundang adanya pro dan kontra di kalangan kaum muslimin. Jangankan sebagai kepala Negara, sebagai kepala rumah tangga pun masih banyak yang keberatan. Masing-masing pendapat tersebut diperkuat dengan dalil yang bersumber pada al-Qur'an dan hadits.(Syaukani, 2021)

Secara umum, Islam tidak melarang perempuan menjadi kepala pemerintahan. Hal itu disebabkan laki-laki dan perempuan adalah sesama hamba Allah yang memiliki kedudukan yang sama di sisi Allah dan akan mendapat balasan yang sama atas amal perbuatannya, seperti dalam QS. Adz-Dzariyaat ayat 56, QS. Al-Hujurat ayat 13, dan QS. An-Nahl ayat 97

sebagai berikut. Artinya: "Dan aku tidak menciptakan jin dan manusia melainkan supaya mereka mengabdi kepada-Ku". (QS. Adz-Dzariyaat [51]:56) Artinya: "Hai manusia, Sesungguhnya Kami menciptakan kamu dari seorang laki-laki dan seorang perempuan dan menjadikan kamu berbangsa bangsa dan bersuku-suku supaya kamu saling kenal-mengenal. Sesungguhnya orang yang paling mulia diantara kamu disisi Allah ialah orang yang paling taqwa diantara kamu. Sesungguhnya Allah Maha mengetahui lagi Maha Mengenal". (QS. Al-Hujurat [49]:13) Artinya: "Barangsiapa yang mengerjakan amal saleh, baik laki-laki maupun perempuan dalam Keadaan beriman, Maka Sesungguhnya akan Kami berikan kepadanya kehidupan yang baik[839] dan Sesungguhnya akan Kami beri Balasan kepada mereka dengan pahala yang lebih baik dari apa yang telah mereka kerjakan”.(QS. An-Nahl [16]:97).

Muhammad Abduh juga pernah mengemukakan bahwa QS. An-Nisa ayat 34 itu tidak dapat dijadikan sebagai alasan bahwa kepemimpinan mutlak berada di tangan laki-laki. Hal ini diperjelas dalam QS. An-Nisa ayat 124 yang menyebutkan bahwa Allah telah menciptakan laki-laki dan perempuan memiliki kemampuan yang sama untuk mengerjakan amal-amal saleh dalam berbagai segi kehidupan. Mereka pun akan mendapatkan hasil atau balasan yang sama. Dari ayat tersebut tampak jelas bahwa Islam memiliki konsep keadilan gender dan tidak mengenal diskriminasi. Ada suatu stereotip gender yang dikaitkan dengan kepemimpinan. Temuan penelitian Schein adalah bahwa laki-laki dan perempuan cenderung melihat pada karakteristik utama manajer yang baik, yaitu memiliki:

1) Kemampuan kepemimpinan

2) Rasa tanggungjawab

3) Keterampilan di bidang bisnis

4) Kemampuan analitis

Perempuan dipandang oleh laki-laki dan perempuan lain, kurang memiliki karakteristik-karakteristik tersebut. Ada sebuah stereotip tentang pekerjaan keras, atau mungkin juga disebut agresif, pemimpin yang lebih asyik dengan tugas daripada relasi atau hubungan. Sebaliknya, manajer perempuan dalam pendidikan cenderung diidentifikasi dengan aspek-aspek manajemen yang lembut.

\section{KESIMPULAN}

Kepemimpinan gender dalam Islam mempunyai posisi yang sangat penting untuk diperhatikan dan dijalankan dengan sebaik mungkin. Pandangan Islam mengenai kepemimpinan harus dipegang oleh orang yang mampu dan dapat menempatkan diri sebagai pembawa kebenaran dengan memberi contoh teladan yang baik, karena pemimpin adalah uswatun hasanah. Ada pendapat yang memperbolehkan perempuan memimpin Negara, ada pula pendapat yang tidak memperbolehkannya. Masing-masing pendapat tersebut diperkuat dengan dalil yang bersumber pada al-Qur'an dan hadits. Hadits yang menjadi rujukan tentang larangan menjadi kepala Negara bagi perempuan adalah sebuah Hadits yang diriwayatkan oleh Abu Bakrah yang artinya "Tidak akan bahagia suatu kaum yang menyerahkan urusan mereka kepada perempuan".Adapun secara umum, Islam tidak melarang perempuan menjadi kepala pemerintahan. 


\section{UCAPAN TERIMA KASIH}

Terimakasih kami haturkan kepada Allah SWT, atas segala Rahmat dan ridhonya sehingga jurnal ini bisa rilis atau terbit. Jurnal ini dapat diselesaikan dengan baik berkat bantuan dari berbagai pihak. kepada Orang Tua atas segala do'a dan dukunganya, sehingga dengan didikanya mampu membuat kami menjadi insan yang selalu semangat dan giat dalam belajar, teimakasih kepada Dosen, Atas segala support dan bimbingannya sehingga jurnal ini bisa terselesaikan dengan baik. Teman, kerabat, atas semua support yang di berikan sehingga membuat penulis tetap bertahan untuk terbitnya jurnal ini.

\section{DAFTAR PUSTAKA}

Bush, T., \& Coleman, M. (2006). Leadership and Strategic Management in Education: Manajemen Strategis Kepemimpinan Pendidikan. Terj: Fahrurrozi, Yogyakarta: IRCiSoD.

Darmojuwono, S. (2000). Pemilihan Kata dalam Iklan Kontak Jodoh sebagai Cerminan Citra Wanita Indonesia" dalam Bambang Kaswanti Purwo. Kajian Serba Linguistik Untuk Anton Moeliono Pereksa.

Harahap, Risma Delima (2016). Keterampilan Guru Mengelola Kelas dan Hubungannya dengan Disiplin Belajar Siswa di SMA Al-Hidayah Bandar Selamat. Jurnal Pembelajaran dan Biologi Nukleus Vol. 2 No. 2

Harahap, Risma Delima (2015). Pengaruh Pemanfaatan Peta Konsep Terhadap Prestasi Belajar Siswa Pada Pokok Bahasan Ekosistem di Kelas VII SMP N 1 BILA HULU AEK NABARA. Jurnal Pembelajaran dan Biologi Nukleua. Vol 1 No. 2

Harahap, Risma Delima (2015). Keterampilan Guru Mengelola Kelas dan Hubungannya dengan Disiplin Belajar Siswa di SMA Al-Hidayah Bandar Selamat Medan 2014. Jurnal Eduscience Vol.2 No, 2

Khairuddin, A. (n.d.). Al-Qur'an dan Terjemahnya, Departemen Agama, Yayasan Penyelenggara Penterjemah/Pentafsir al-Qur'an, 1986. Abdul Wahhab Khallaf, Ilmu Ushul Fiqh, al .... Core.Ac.Uk. https://core.ac.uk/download/pdf/45430396.pdf

Mosse, J. C. (2007). Half the Word, Harf A Chance, An Introduction to Gender and Development,(terj), Hartian Silawati, Gender dan Pembangunan. In Yogyakarta: RIFKA ANNISA Women's Crisis Center

Mufidah, C. (2003). Paradigma gender. digilib.fisipol.ugm.ac.id. http://digilib.fisipol.ugm.ac.id /handle/15717717/11192

Riant, N. (2008). Gender dan Strategi Pengarus-Utamaannya di Indonesia. In Yogyakarta: Pustaka Pelajar.

Rohyani, E. S. (2015). Pemikiran Pendidikan Agama Islam dalam Perspektif Prof. Achmadi. MUDARRISA: Journal of Islamic Education, 5(2), 173. https://doi.org/10.18326/mdr.v7i2.753

Romdloni, R. (1978). Book Review: The TAO of Islam. Review of Social Economy.

Sukri, S. S. (2002). Pemahaman Islam dan Tantangan Keadilan Jender. Yogyakarta: Gama Media.

Syaukani, S. Y. (2021). PEMIKIRAN FATIMA MERNISSI TENTANG PENDIDIKAN ISLAM PERSPEKTIF GENDER. TaLimuna: Jurnal Pendidikan Islam. https://e-journal.staimaalhikam.ac.id/index.php/talimuna/article/view/489 
Umi, S. (2008). Spektrum Gender. Malang. UIN-Malang Press.

Wahyuni, Z. M., Lestari, F., \& Hasanah, U. (2020). Kepemimpinan Dan Gender Dalam Lembaga Pendidikan Islam. PRODU: Prokurasi Edukasi Jurnal Manajemen Pendidikan Islam, 2(Special), 26-37.

Yatazaka, Y. (2014). Gender Dan Pengembangan Pemikiran Pendidikan Islam. Jurnal Pendidikan Islam. 